\title{
A rapid method for isolation of genomic DNA from food-borne fungal pathogens
}

\author{
S. Umesha ${ }^{1} \cdot$ H. M. Manukumar ${ }^{1} \cdot$ Sri Raghava ${ }^{1}$
}

Received: 22 October 2015/Accepted: 25 May 2016/Published online: 6 June 2016

(c) The Author(s) 2016. This article is published with open access at Springerlink.com

\begin{abstract}
Food contaminated with fungal pathogens can cause extremely harmful effects to human even when present in low concentrations. Researchers now pay more attention towards rapid DNA extraction for the quick screening, which is highly demanded in diverse research field. Molecular description of many fungal species is identified by different molecular characteristics. Hence, the efficient isolation of genomic DNA and amplification using PCR is a prerequisite for molecular characterization. Here, we used an improved Sodium dodecyl sulfate-Cetyltrimethyl ammonium bromide-Chloroform-isoamyl alcohol method by combining Sodium dodecyl sulfate with cetyl methylammonium bromide without addition of proteinase $\mathrm{K}$, RNase $\mathrm{K}$, and $\beta$-mercaptoethanol. To analyze the quality of recovered DNA, this method was compared with the other four routine methods. The present method has been chosen in the study as a preferred method because of easy adaptation to routine laboratories/food industries considering its rapid, sensitivit,y and cost effectiveness involved in the method.
\end{abstract}

Keywords CTAB $\cdot$ TPCI $\cdot$ MW $\cdot$ S-CCI $\cdot$ PCR $\cdot$ DNA

\section{Introduction}

In under-developed countries, one of the leading causes of illness and death is due to food-borne pathogens, which accounts approximately up to 1.8 million people annually

S. Umesha

umeshgroup@yahoo.co.in; pmumesh@gmail.com;

su@appbot.uni-mysore.ac.in

1 Department of Studies in Biotechnology, University of Mysore, Manasagangotri, Mysore 570006, Karnataka, India
(Bisha and Brehm-Stecher 2010). To ensure food safety, rapid detection of pathogenic organisms causing food-borne illness is a basic requirement. Plating methods have been replaced by more rapid and sensitive methods, such as Fluorescence In-Situ Hybridization (FISH) (Chattopadhyay et al. 2013), Enzyme Linked Immuno-Sorbent Assays (ELISA) (Naravaneni and Jamil 2005), Polymerase Chain Reaction (PCR) (Jaykus 2003), and Real-Time PCR (RTPCR) (Wolffs et al. 2004). However, the prerequisite for all these methods is a high-quality DNA from the pathogen. Various procedures are being used in these contests, but these protocols are mainly suited for specific groups with known morphologies and not for versatile fungal groups. Therefore, DNA extraction is a very critical step, as it eliminates unwanted interfere substances and ensures consistency in the nucleic acid test results (Bolano et al. 2001).

It is a well-known fact that extraction of pure DNA from fungi is very difficult. Reports exist that DNA extracted from Neotyphodium lolii (Christensen et al. 1993) using methods of Raeder and Broda (1985) and Byrd et al. (1990) that was neither digested nor amplified by restriction enzymes and Taq polymerase, respectively. This was mainly due to cross contamination of fungal polysaccharides or agar inoculum taken from the plates. Recently commercial kits have been popularized (Dieguez et al. 2009), because DNA can be extracted easily within a day. Since the available kit-based and other DNA extraction methods are time consuming, and expensive. researchers have also worked with different approaches to explore the best manual method to extract fungal DNA, such as CTAB (Petrisko et al. 2010) with organic solvents, lyticase, phenol-chloroform, and isoamylic alcohol (Shin-ichi and Takuma 2010) chelex (Hennequin et al. 1999) and the urea chelex method (Mseddi et al. 2011) for some fungal mycelia and most fungal spore samples remain undesirable. 
In this present paper, Sodium dodecyl sulfate-Cetyltrimethyl ammonium bromide-Chloroform-isoamyl alcohol (S-CCI) method was used for the isolation of food-borne fungal genomic DNA. Sodium dodecyl sulfate (SDS) is a strong anionic detergent, which disrupts non-covalent bonds in the proteins and denature or losing its confirmation. Cell membrane composed of proteins and lipids in varying percentage. When external force/chemicals applied, then membrane act against defence and become destabilized this leads to breakdown of nuclear envelop and expose of nuclear material to the outer environment. In addition, removing the membrane barriers helps to release the DNA from histones and other DNA-binding proteins by denaturing them. The CTAB extraction method originally developed by Doyle and Doyle in 1987, and later, it was modified to remove polysaccharide, polyphenols, and other secondary metabolites. The superfluous quantities of cellular proteins were eliminated by triple extended treatment with chloroform-isoamyl alcohol. In addition to the removal of proteins, this treatment also helps to remove different coloring substances. Importantly, CTAB is probably the only compound that can separate partial nucleic acids from polyphenols. The polyphenolic compounds may severely inhibit downstream DNA/RNA reactions. Chloroform-isoamyl alcohol is a type of liquid detergent disrupts the bonds that hold the cell membranes by dissolving proteins, lipids, and then form complexes to precipitate out of the solution.

The modified extraction protocol was designed based on four factors, to maximize the DNA yield, minimize the time, and avoid the use of expensive chemicals in extraction steps, and DNA should be amenable to several downstream enzymatic applications, such as PCR amplification. Therefore, the objective of this study was to compare existing extraction methods to our modified S-CCI protocol for high-quality total DNA from fungi, such as Aspergillus niger, Aspergillus flavus, Aspergillus fumigates, Acremonium strictum, Bipolaris cyanodontis, Colletotrichum gloeosporioides, Fusarium equiseti, Fusarium oxysporum, Penicillium, and Trichoderma.

\section{Materials and methods}

\section{Sample collection and Isolation of mycoflora}

Different vegetarian and non-vegetarian food samples were collected from different locations of Mysore region and sterilized with $3 \%$ sodium hypochlorite, $70 \%$ ethanol, and followed by repeated washings with sterile distilled water. All samples were subjected to non-selective medium, potato dextrose agar (PDA), and incubated at $25 \pm 2{ }^{\circ} \mathrm{C}$ for 7 days. Then, fungal cultures were identified based on morphological characteristics using standard book by Mathur and Kongsdal, (2003) and pathogens were purified by culturing onto new plates and individual cultures were inoculated into potato dextrose broth (PDB) followed by incubation for 10 days at $25 \pm 2{ }^{\circ} \mathrm{C}$. Grown mycelial mat was freeze dried (at $-20{ }^{\circ} \mathrm{C}$ ), lyophilized (at $-50{ }^{\circ} \mathrm{C}$ ), and further DNA isolation and purification procedure were carried out for these samples.

\section{Reference strain}

The reference Aspergillus brasiliensis (MTCC-1344) fungal strain was kindly gifted by Ananda, A. P., Department of Microbiology, Ganesh consultancy, and analytical services, Mysore. Cultures acquired from Microbial Typing Culture Collection, Chandigarh, India, used as positive control for experimental study, and culture was revived and grown as per protocol prescribed.

\section{Genomic DNA extraction methods}

\section{CTAB-phenol-chloroform-isoamyl alcohol method}

$200 \mathrm{mg}$ of lyophilized mycelial mat were grounded with pestle and mortar using $500 \mu \mathrm{L}$ of [CTAB-phenol-chloroform-isoamyl alcohol method (CTABPCI)] extraction buffer (200-mM Tris-HCl (pH 8.0), 25-mM EDTA (pH 8.0), 250-M NaCl, $10 \% \mathrm{CTAB}$ ) according to $\mathrm{Li}$ and Yao (2005). Transferred to fresh tube and $3-\mu \mathrm{L}$ proteinase $\mathrm{K}$, 3- $\mu \mathrm{L}$ RNase were added then vortex and incubated for $1 \mathrm{~h}$ at $37{ }^{\circ} \mathrm{C}$. After incubation tubes were kept in a water bath for $10 \mathrm{~min}$ at $65{ }^{\circ} \mathrm{C}$. After one volume of phenol: chloroform: isoamyl alcohol $(25: 24: 1)$ was added, solution was thoroughly mixed for $5 \mathrm{~min}$ then centrifuged at 12,000 rpm for $5 \mathrm{~min}$. The aqueous clear phase was recovered and mixed with one volume of chloroform: isoamyl alcohol (24:1), centrifuged at $12,000 \mathrm{rpm}$ for $5 \mathrm{~min}$, and the aqueous phase was recovered. Added one volume of icecold isopropanol and stored overnight for precipitation of DNA at $-20{ }^{\circ} \mathrm{C}$. DNA was recovered by centrifugation at $10,000 \mathrm{rpm}$ for $5 \mathrm{~min}$ and DNA was precipitated with absolute ethanol. The DNA was then rinsed twice with $1 \mathrm{ml}$ of $70 \%$ ethanol and resuspended in $200 \mu \mathrm{L}$ of deionized water or $1 \mathrm{X}$ TE [200-mM Tris- $\mathrm{HCl}(\mathrm{pH} \mathrm{8.0)}$, 20-mM EDTA (pH 8.0)] buffer for further use.

\section{Tris-phenol-chloroform-isoamyl alcohol method}

Lyophilized $200 \mathrm{mg}$ of fungal cultures were transferred to 2-ml fresh tubes. $500 \mu \mathrm{L}$ of TPCI (Tris-phenol-chloroform-isoamyl alcohol) extraction buffer (10 mM Tris- $\mathrm{HCl}$, $\mathrm{pH}$ 8.0, $100 \mathrm{mM} \mathrm{NaCl}, 25 \mathrm{mM}$ EDTA, $0.5 \%$ SDS), and 3 $\mu \mathrm{L}$ proteinase $\mathrm{K}$ was added, vortexed, and incubated for 
$1 \mathrm{~h}$ at $37{ }^{\circ} \mathrm{C}$. Tubes were kept in a water bath for $10 \mathrm{~min}$ at $65^{\circ} \mathrm{C}$ and centrifuged at $10,000 \mathrm{rpm}$ for $10 \mathrm{~min}$. Upper liquid part was carefully transferred to a new tube and one volume of phenol: chloroform: isoamyl alcohol (25:24:1) mixed thoroughly for $5 \mathrm{~min}$ and centrifuged at 10,000 rpm for $5 \mathrm{~min}$. The aqueous phase was recovered, added $3-\mu \mathrm{L}$ RNase, and incubated for $30 \mathrm{~min}$. Mixed with one volume of chloroform: isoamyl alcohol (24:1), and tubes were centrifuged at $10,000 \mathrm{rpm}$ for $5 \mathrm{~min}$. Again, the aqueous phase was recovered and one volume of ice-cold isopropanol was added and the tubes were stored overnight at $-20{ }^{\circ} \mathrm{C}$. After centrifugation at $10,000 \mathrm{rpm}$ for $5 \mathrm{~min}$, the pellet was recovered and DNA was precipitated with absolute ethanol. The DNA was then washed twice with $1-\mathrm{ml} 70 \%$ ethanol and resuspended in $200 \mu \mathrm{L}$ of deionized water as per Silva et al. (2014).

\section{Microwave method}

The cultures were collected and grown as described above, and the gDNA was purified by the microwave (MW) method as reported previously by Bollet et al. (1995). $200 \mathrm{mg}$ of fungal mat was rinsed with 1-ml TE buffer, centrifuged, and lysed with $100-\mu \mathrm{L}$ TE buffer and $50-\mu \mathrm{L}$ $10 \%$ SDS. Incubated for $30 \mathrm{~min}$ at $65{ }^{\circ} \mathrm{C}$ and centrifuged to remove the supernatant. The cell pellet was placed in a microwave oven, heated two times for $1 \mathrm{~min}$ at $900 \mathrm{~W}$. The pellet was then resuspended in $200-\mu \mathrm{L}$ TE buffer with one volume of phenol: chloroform: isoamyl alcohol (25:24:1) for $15 \mathrm{~min}$. The aqueous phase was recovered by centrifugation; the DNA was precipitated with $95 \%$ ethanol and centrifuged at $12,000 \mathrm{rpm}$ for $20 \mathrm{~min}$. Then, the DNA was rinsed with 1-ml $70 \%$ ethanol and resuspended in $200-\mu \mathrm{L}$ deionized water as previously described.

\section{Inexpensive method}

Fungal cultures were collected and grown as described above for inexpensive DNA extraction (IM) method as reported previously by Prabha et al. (2012). $200 \mathrm{mg}$ of lyophilized mycelia mat were rinsed with 1-ml TE buffer, vortexed for $10 \mathrm{~s}$, tubes were kept at room temperature for $30 \mathrm{~min}$. After centrifugation (10,000 rpm for $10 \mathrm{~min})$, supernatant was transferred to a new tube, then, the equal volume of phenol: chloroform (24:1) was added, mixed properly, and centrifuged at 13,000 rpm for $2 \mathrm{~min}$. Finally, supernatant was collected into separate tube, $300 \mu \mathrm{L}$ of icecold isopropanol was added and gently mixed in tubes inversely. The reaction mixture was incubated at $-20{ }^{\circ} \mathrm{C}$ for $30 \mathrm{~min}$. DNA was recovered by centrifugation at $13,000 \mathrm{rpm}$ for $5 \mathrm{~min}$ and pellet was washed with ice-cold $70 \%$ ethanol and air dried for $15 \mathrm{~min}$ at room temperature.
Finally, pellet was resuspended in $100 \mu \mathrm{L}$ of sterile water and stored at $-20{ }^{\circ} \mathrm{C}$ for further use.

\section{SDS-CTAB-chloroform-isoamyl alcohol (modified method)}

$200 \mathrm{mg}$ of lyophilized mycelial powder was taken and transferred to 2-ml eppendorf tube. $500 \mu \mathrm{L}$ of SDS-CTABchloroform-isoamyl alcohol (S-CCI) extraction buffer (250-mM Tris-HCl (pH 8.0), 20-mM EDTA (pH 8.0), 200-M NaCl, $10 \%$ CTAB, $0.15 \%$ SDS) was added and vortexes and boiled for $10 \mathrm{~min}$ at $50{ }^{\circ} \mathrm{C}$ and centrifuged at $10,000 \mathrm{rpm}$ for $10 \mathrm{~min}$. Carefully, upper liquid part was pipetted out and one volume of chloroform: isoamyl alcohol (23:2) was added then mixed for 1 min and centrifuged at 10,000 rpm for $5 \mathrm{~min}$. The aqueous phase was recovered and mixed with one volume of ice-cold isopropanol, and tube was turned upside down for $1 \mathrm{~min}$ to precipitate DNA. Tubes were centrifuged at 10,000 rpm for 2 min to recover the pellet and washed with $500 \mu \mathrm{L}$ of absolute ethanol, then centrifuged at $10,000 \mathrm{rpm}$ for $1 \mathrm{~min}$. DNA was air dried and resuspended in $200-\mu \mathrm{L}$ deionized or TE buffer for further use.

\section{DNA quantification and quality determination}

Extracted genomic DNA concentration and purity were determined by NanoDrop spectrophotometer (Thermo Fisher Scientific, USA). Concentration was recorded in $\mathrm{ng} / \mu \mathrm{L}$, and purity of DNA is based on the ratio of the optical density (OD) at the wavelength of $260 \mathrm{~nm}$ and $280 \mathrm{~nm}$. The quality of the DNA yielded by each method was determined by gel electrophoresis in a $0.7 \%$ agarose gel.

\section{Restriction digestion}

According to Devi et al. (2015) with slight modifications, quality of the genomic DNA was validated using Eco RI (Fermentas, Germany) restriction enzyme. The S-CCI method extracted DNA was subjected for enzyme digestion (one sample per triplicate) to check the suitability of the DNA for downstream applications. Reaction volume set for $20 \mu \mathrm{L}$ contain $5 \mu \mathrm{L}$ of $10 \mathrm{X}$ assay buffer [ $1 \mathrm{X}$ buffer composition: 10-mM Tris- $\mathrm{HCl} \quad \mathrm{pH} \quad 8.0 ; \quad 5-\mathrm{mM}$ $\mathrm{MgCl}_{2} ; 100-\mathrm{mM} \mathrm{KCl} ; 0.02 \%$ TritonX-100; $0.1-\mathrm{mg} / \mathrm{mL}$ BSA], 1-2 $\mu \mathrm{g}$ of the DNA template with $20 \mathrm{U}$ of the enzyme, and reaction volume make up using $1 \mathrm{X}$ enzyme buffer. Then, reaction carried out at $37^{\circ} \mathrm{C}$ for $20-60 \mathrm{~min}$ in water bath. Finally, reaction was stop by heat inactivating the enzyme at $65{ }^{\circ} \mathrm{C}$ for $10 \mathrm{~min}$ and $5 \mu \mathrm{L}$ of the digested products were analyzed on $0.8 \%$ agarose gel along with $1 \mathrm{~Kb}$ DNA ladder. 


\section{Polymerase Chain Reaction}

Polymerase Chain Reaction (PCR) assay was performed using ITS rDNA primers. According to Gonzalez et al. (2008), PCR amplification reaction was performed using ITS1 F (TCCGTAGGTGAACCTGCGG) and ITS4 R (TCCTCCGCTTATTGATATGC) primer set. Amplification was carried out in $0.2-\mathrm{ml}$ tube and reaction mixture containing $2.5 \mu \mathrm{L}$ of $80-100 \mathrm{ng}$ of genomic DNA, $1 \mu \mathrm{L}$ of 20 pmol of each primer, and $20 \mu \mathrm{L}$ of Dream Taq Green PCR master mix (Containing: $0.25 \mathrm{mM}$ each dNTP, $2 \mathrm{mM}$ $\mathrm{MgCl}_{2}$ and Taq DNA polymerase) purchased from (Thermo scientific, India). The PCR was performed in a master gradient thermal cycler (LABNET, NJ, USA) using the following conditions: initial denaturation at $94{ }^{\circ} \mathrm{C}$ for $5 \mathrm{~min}$; 30 cycles of denaturation for $1 \mathrm{~min}$ at $94{ }^{\circ} \mathrm{C}$, annealing for $1 \mathrm{~min}$ at $52{ }^{\circ} \mathrm{C}$, initial extension for $1 \mathrm{~min}$ at $72{ }^{\circ} \mathrm{C}$, and final extension of $10 \mathrm{~min}$ at $72{ }^{\circ} \mathrm{C}$, followed by cooling at $4{ }^{\circ} \mathrm{C}$ until the samples were recovered. The amplified PCR amplicons was confirmed through gel electrophoresis using $1 \%$ agarose gel.

\section{Results and discussion}

Due to the presence of cell wall in fungi, it interferes and hinders the efficiency of DNA extraction from the conventional extraction methods (Maaroufi et al. 2004). After several repetitions, we have optimized rapid and inexpensive method to isolate of fungal DNA by slight modifications in the existing CTAB buffer constitution and steps involved in DNA extraction (Rogers 1989). The yield and purity of genomic DNA obtained from all four extraction methods are depicted in Table 1. Different species of microorganisms having its own varied membrane structural organization with unique sets of protein to carry out the specialized functions (Arachea et al. 2012). In the present study, four different detergents-based protocol for disruption of membrane structure and removal of proteins (irreversibly from the cell) have been compared. The high DNA yield was obtained in S-CCI protocol $(645.45 \mu \mathrm{g} / \mathrm{g}$ sample for Trichoderma) followed by CTABPCI, TPCI, MW, and IM in descending order was represented in Table 1. It is evident from the data that protocol IM recovered very less yield compared to the other methods. In Fig. 1, the highest yield of DNA extracted by different methods was depicted.

The purity of DNA from fungal pathogens using S-CCI protocol was followed according to the $\mathrm{Ki}$ et al. (2007); Desloire et al. (2006) and results depicted in Table 1. The S-CCI extracted genomic DNA of fungal pathogens was
Table 1 Genomic DNA yield from different fungal pathogens using different extraction methods

\begin{tabular}{|c|c|c|c|c|}
\hline $\begin{array}{l}\text { S1. } \\
\text { no }\end{array}$ & Method & Pathogens & $\begin{array}{l}\text { Yield ( } \mu \mathrm{g} \\
\text { DNA/g } \\
\text { sample) }\end{array}$ & $\begin{array}{l}\text { Purity } \\
\left(\mathrm{A}_{260}\right) \\
\left.\mathrm{A}_{280}\right)\end{array}$ \\
\hline \multirow[t]{10}{*}{1} & \multirow[t]{10}{*}{ CTABPCI } & Aspergillus niger & 301.25 & 1.90 \\
\hline & & Aspergillus flavus & 246.95 & 1.67 \\
\hline & & Bipolaris cyanodontis & 210.52 & 1.92 \\
\hline & & Fusarium oxysporum & 239.57 & 2.01 \\
\hline & & Penicillium & 250.45 & 2.10 \\
\hline & & Trichoderma & 280.00 & 1.96 \\
\hline & & Fusarium equiseti & 219.95 & 1.87 \\
\hline & & Acremonium strictum & 195.30 & 2.00 \\
\hline & & $\begin{array}{l}\text { Colletotrichum } \\
\text { gloeosporioides }\end{array}$ & 236.20 & 1.98 \\
\hline & & Aspergillus fumigatus & 210.30 & 1.65 \\
\hline \multirow[t]{10}{*}{2} & \multirow[t]{10}{*}{ TPCI } & Aspergillus niger & 108.85 & 1.75 \\
\hline & & Aspergillus flavus & 33.97 & 1.94 \\
\hline & & Bipolaris cyanodontis & 158.62 & 2.01 \\
\hline & & Fusarium oxysporum & 97.27 & 1.84 \\
\hline & & Penicillium & 151.00 & 1.99 \\
\hline & & Trichoderma & 200.45 & 2.10 \\
\hline & & Fusarium equiseti & 51.97 & 2.21 \\
\hline & & Acremonium strictum & 167.52 & 2.10 \\
\hline & & $\begin{array}{l}\text { Colletotrichum } \\
\text { gloeosporioides }\end{array}$ & 172.13 & 1.69 \\
\hline & & Aspergillus fumigatus & 171.85 & 1.85 \\
\hline \multirow[t]{10}{*}{3} & \multirow[t]{10}{*}{ MW } & Aspergillus niger & 34.67 & 1.40 \\
\hline & & Aspergillus flavus & 189.05 & 2.10 \\
\hline & & Bipolaris cyanodontis & 110.25 & 1.78 \\
\hline & & Fusarium oxysporum & 70.32 & 1.75 \\
\hline & & Penicillium & 244.50 & 1.98 \\
\hline & & Trichoderma & 189.67 & 2.10 \\
\hline & & Fusarium equiseti & 185.67 & 1.89 \\
\hline & & Acremonium strictum & 46.75 & 1.78 \\
\hline & & $\begin{array}{l}\text { Colletotrichum } \\
\text { gloeosporioides }\end{array}$ & 105.52 & 1.70 \\
\hline & & Aspergillus fumigatus & 197.39 & 1.50 \\
\hline \multirow[t]{10}{*}{4} & \multirow[t]{10}{*}{ IM } & Aspergillus niger & 113.21 & 1.84 \\
\hline & & Aspergillus flavus & 211.32 & 1.98 \\
\hline & & Bipolaris cyanodontis & 78.05 & 2.20 \\
\hline & & Fusarium oxysporum & 127.60 & 2.01 \\
\hline & & Penicillium & 184.72 & 1.45 \\
\hline & & Trichoderma & 220.42 & 1.79 \\
\hline & & Fusarium equiseti & 152.60 & 1.99 \\
\hline & & Acremonium strictum & 67.75 & 2.00 \\
\hline & & $\begin{array}{l}\text { Colletotrichum } \\
\text { gloeosporioides }\end{array}$ & 211.00 & 1.89 \\
\hline & & Aspergillus fumigatus & 235.47 & 1.98 \\
\hline
\end{tabular}


Table 1 continued

\begin{tabular}{lllll}
\hline $\begin{array}{l}\text { Sl. } \\
\text { no }\end{array}$ & Method & Pathogens & $\begin{array}{l}\text { Yield }(\mu \mathrm{g} \\
\mathrm{DNA} / \mathrm{g} \\
\text { sample) }\end{array}$ & $\begin{array}{l}\text { Purity } \\
\left(\mathrm{A}_{260} /\right. \\
\left.\mathrm{A}_{280}\right)\end{array}$ \\
\hline 5 & \multirow{2}{*}{ S-CCI } & Aspergillus niger & 306.47 & 1.99 \\
& & 596.15 & 1.93 \\
& Aspergillus flavus & 314.80 & 2.01 \\
& Bipolaris cyanodontis & 390.02 & 2.00 \\
& Fusarium oxysporum & 359.47 & 1.70 \\
& Penicillium & 645.45 & 1.83 \\
& Trichoderma & 354.92 & 2.01 \\
& Fusarium equiseti & 253.53 & 1.72 \\
& Acremonium strictum & 305.07 & 1.69 \\
& Colletotrichum & & \\
& gloeosporioides & & 1.78 \\
& Aspergillus fumigatus & 249.36 &
\end{tabular}

Different fungal cultures were used for extraction of DNA by CTABPCI, TPCI, MW, and IM compared to modified S-CCI method in this study. Yield and purity of established S-CCI method were compared to other methods. Each values of yield and purity mentioned are average of triplicate assay carried out for all the fungal pathogens used

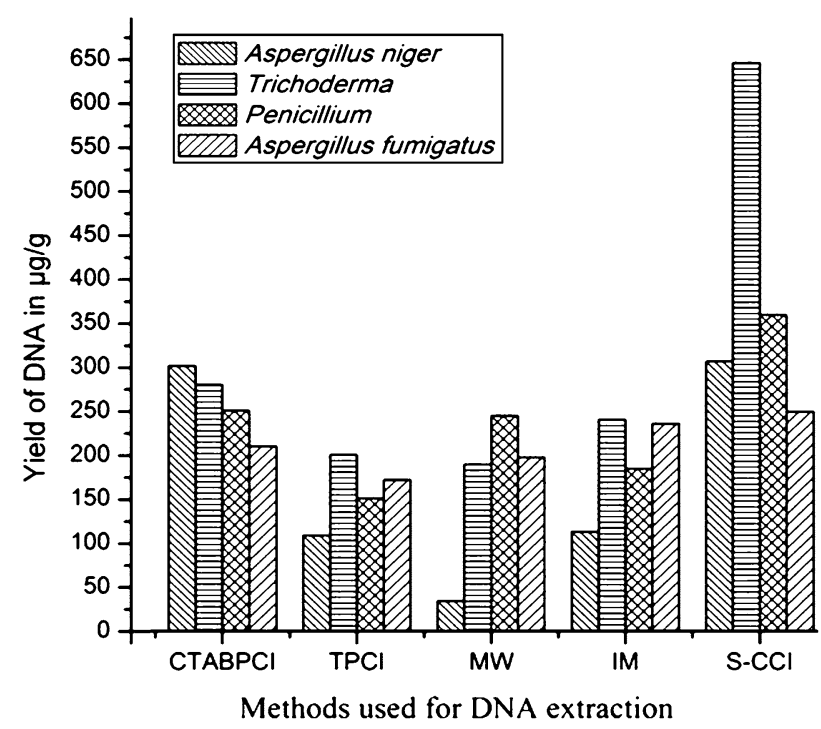

Fig. 1 Yield of DNA in different DNA extraction methods. Different fungal genomic DNA was prepared by CTABPCI, TPCI, MW, IM, and modified $\mathrm{S}-\mathrm{CCI}$ methods. Highest DNA yield was obtained by the S-CCI method from Aspergillus niger, Trichoderma, Penicillium, and Aspergillus fumigates compared to the other methods of DNA extraction. Among different DNA extraction methods, the S-CCI method showed maximum yield of DNA

run on $0.7 \%$ agarose gel (Fig. 2), to compare the quality of DNA. The CTAB method has been primarily developed for extraction of DNA from plant tissues. This superior method helps in removing unwanted carbohydrates associated during plant DNA extraction (Goltapeh et al. 2007; Petrisko et al. 2008a, b). Muller et al. (1998) reported high-

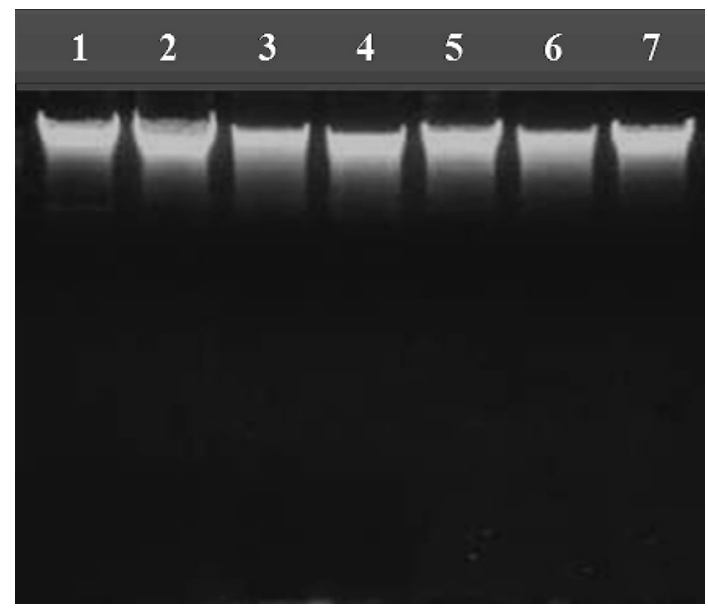

Fig. 2 Genomic DNA profile of different fungi, extracted using S-CCI method on $0.7 \%$ agarose gel. Genomic DNA was extracted from different fungi using S-CCI method and electrophoresed on $0.7 \%$ agarose gel. S-CCI method showed clear DNA profile of all fungal organism studied. Lane 1. Aspergillus niger, 2. Aspergillus flavus, 3. Bipolaris cyanodontis, 4. Fusarium oxysporum, 5. Penicillium, 6. Trichoderma, and 7. Fusarium equiseti

speed cell disruption extraction produced a significantly greater yield from fungi. Fredricks et al. (2005) used a FDNA followed the same principle accordance with the Muller, and it is comparable to our S-CCI protocol. According to Liu et al. (2011), FPFD (Fast Purification of Fungal DNA) method also promisingly explained satisfactory recovery of fungal DNA from FPFD experimental performance. FPFD method does not require organic extraction, and this method meet the needs of the routine screening of fungal pathogens. All methods except TPCI and MW method highlighted cross contamination of protein in the sample were depicted in Table 1. Values of an OD ratio factor of the purity of DNA; below 1.8 indicates protein contamination while above 1.8 indicates contamination of RNA (Samuel et al. 2003). The purity of DNA was compared among different methods that were represented in Table 1. The purity of the all the DNA was further confirmed by digesting the genomic DNA using restriction enzyme Eco RI. Then, photograph was showing the banding pattern of digested DNA along with genomic DNA in Fig. 3, it is comparable to the Ajay et al. (2008).

Important features of this S-CCI protocol are: 1. The method works well with all species of fungus to extract genomic DNA. 2. Yields high quality of DNA from mycelium without fragmentation of DNA. 3. Very simple, cost effective, and requires less manpower. 4. Compared to kit-based methods, this method is quite fast with less extraction steps and chemicals required. According to Khan and Yadav (2004), excessive or above $0.01 \%$ of SDS residues in the sample cause denaturation of the Taq DNA polymerase or crass act or inhibit the PCR 


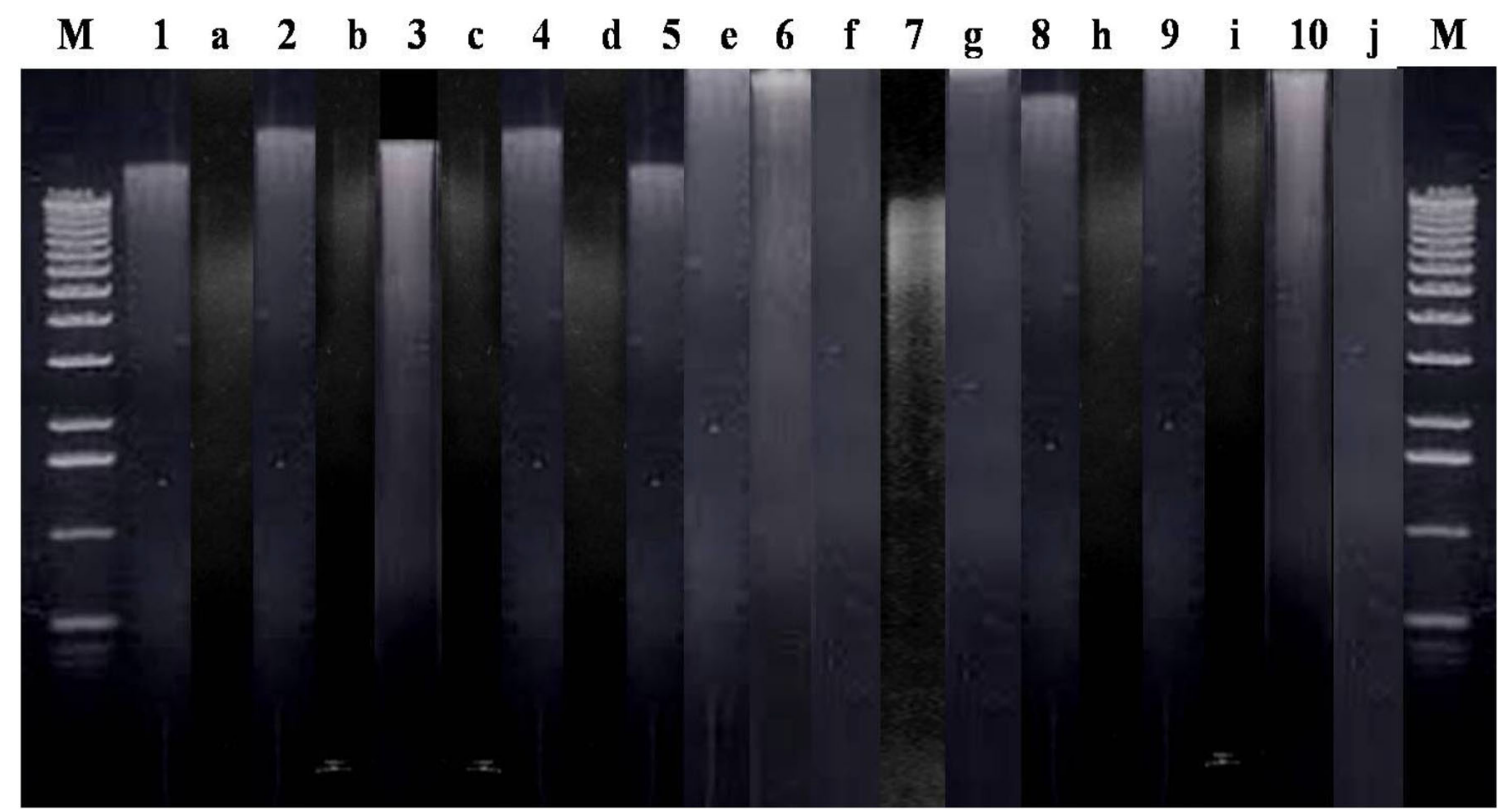

Fig. $3 \mathrm{Gel}$ electrophoresis of partial restriction digestion of the genomic DNA extracted by the S-CCI method using restriction enzyme Eco RI. Compared to CTABPCI, TPCI, MW, and IM DNA extraction methods, S-CCI exhibited its downstream application showing less contamination, while extracting DNA of fungal pathogens. Lane 1. Aspergillus niger, 2. Aspergillus flavus, 3.

amplification; so, use of less percentage of SDS is must required. Therefore, in our study, we have used $0.15 \%$ of SDS in the S-CCI method; hence, no cross acting on PCR was observed. So, we recommend not more than $0.15 \%$ of SDS (higher may affect the PCR) to prepare the S-CCI extraction buffer.

To check the quality of fungal genomic DNA, fungal Internal Transcribed Spacer (ITS) specific universal primers ITS1F and ITS4R were used for amplification of the fungal rDNA region. Figure 4, represents ITS primer amplified PCR products of S-CCI extracted DNA of different fungi (morphological characteristics were depicted in Fig. 5), which have been well resolved in $1 \%$ agarose gel and compared to 100-bp ladder. Confirmed that the DNA sample are free of polyphenols and polysaccharides, which are inhibitory agents hidden in the sample known to inhibit restriction endonucleases (RE) and Taq DNA polymerase according to Moyo et al. (2008). Restriction enzyme digested samples in Fig. 3 also confirmed that isolated DNA was amenable for downstream applications was successfully explained in the paper is comparable to the Ajay et al. (2008).

Fredricks et al. (2005) compared two important human fungal pathogens (Aspergillus fumigatus and Candida albicans) using six kit-based DNA extraction protocol. Among them, MPY (Master Pure Yeast DNA purification kit) and FDNA protocol produced a good result yielding
Bipolaris cyanodontis 4. Fusarium oxysporum, 5. Penicillium, 6. Trichoderma 7. Fusarium equiseti, 8. Acremonium strictum, 9. Colletotrichum gloeosporioides, and 10. Aspergillus fumigatus followed by restriction digestion products $(a-j)$, respectively, on $1 \%$ agarose gel. Lane $M 1 \mathrm{~kb}$ DNA ladder

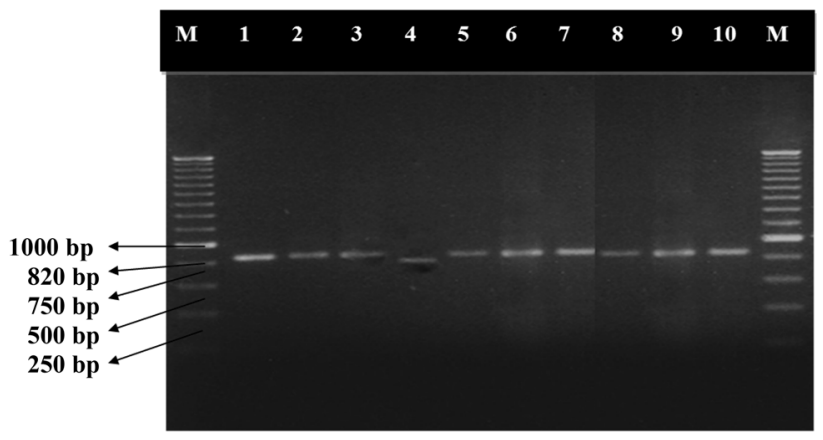

Fig. 4 Amplified PCR profile of different fungal ribosomal DNA extracted from the S-CCI method. Among the different (CTABPCI, TPCI, MW, and IM) methods, downstream application of PCR was well-defined by the S-CCI method. The PCR was performed using ITS1 and ITS4 primers and electrophoresed on $1 \%$ agarose gel. Lane 1. Aspergillus niger, 2. Aspergillus flavus, 3. Bipolaris cyanodontis, 4. Fusarium oxysporum, 5. Penicillium, 6. Trichoderma, 7. Fusarium equiseti, 8. Acremonium strictum, 9. Colletotrichum gloeosporioides, and 10. Aspergillus fumigatus

the high amount of fungal DNA. In comparison to kitbased protocol and available existing DNA extraction methods, S-CCI executionproved that it is more advantageous, yielding more fungal DNA over kit-based MPY, FDNA, and compared four methods in this study. Fredricks method of DNA isolation has a major drawback of low yield of DNA. To overcome this drawback, necessay link was highlighted in the S-CCI method by altering chemical 

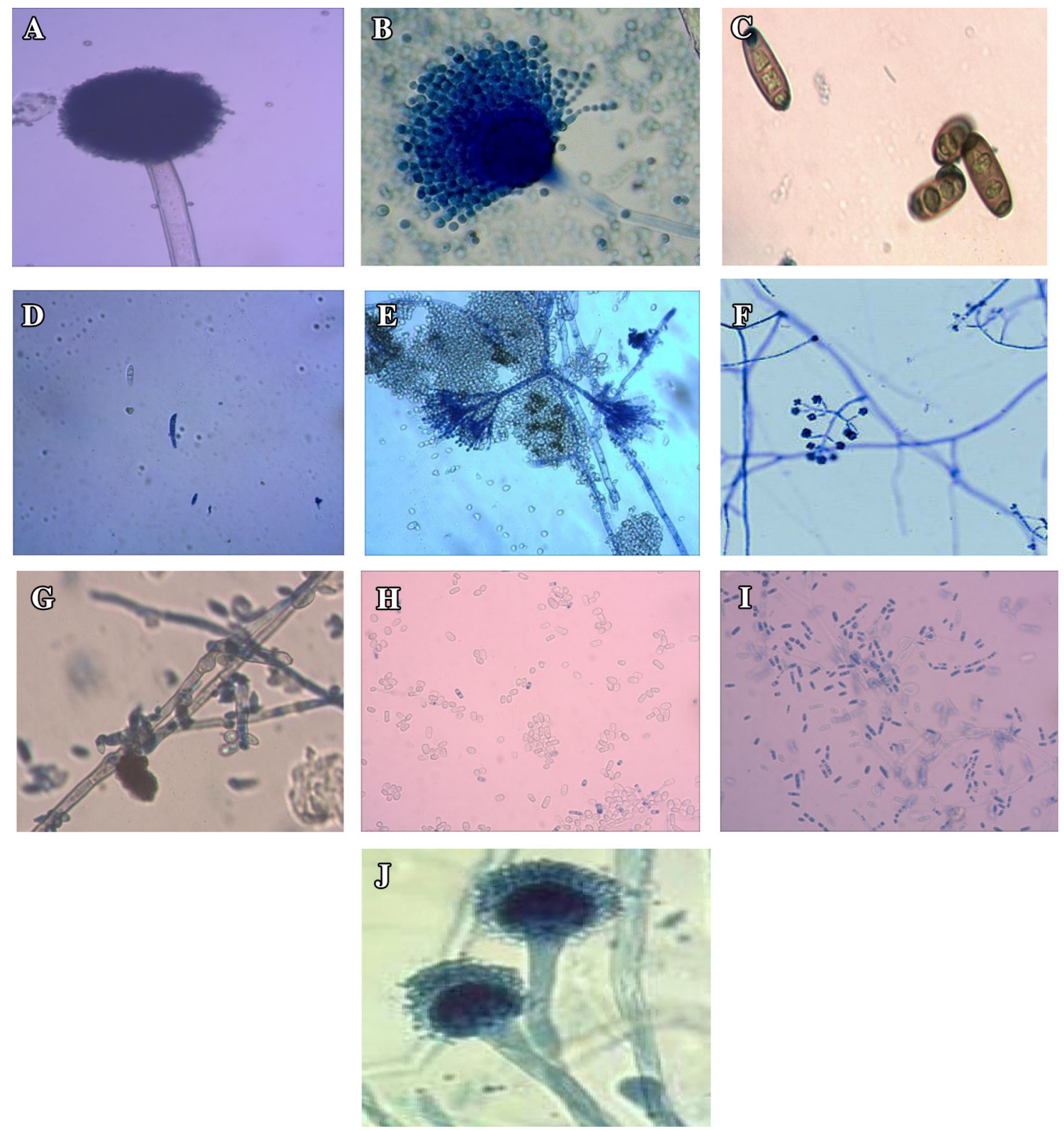

Fig. 5 Morphological characterization of fungal pathogens under compound microscope. Different fungal pathogens cultured on PDA medium were subjected to morphological characterization under compound microscope. a Aspergillus niger, b Aspergillus flavus,

compositions and steps important for the recovery of fungal DNA method was optimized in this paper.

Some of the species grow as unicellular that reproduce by budding or binary fission in case of yeasts. However, dimorphic fungi can grow in between a yeast phase and a hyphal phase in response to environmental conditions. Plants cell wall composed of glucans and exoskeleton of arthropods made by chitin. But in the case of fungal cell, celwall is composed of both chitin and glucans. The only organisms combine both these structural molecules in their cell wall. Except plants and oomycetes, cell walls of fungi c Bipolaris cyanodontis, d Fusarium oxysporum, e Penicillium, f Trichoderma, g Fusarium equiseti, $\mathbf{h}$ Acremonium strictum, i Colletotrichum gloeosporioides, and $\mathbf{j}$ Aspergillus fumigatus

do not contain cellulose. Fungi are one of the most successful species and are distributed worldwide. The cell wall of a fungus is an intriguing component. It determines the shape of the cell and also protects cell from harsh environment.

The fungal kingdom is very diverse in nature, species growing as unicellular, or hyphae with branches helps in production of remarkable assortment of spores and other reproductive structures. For every stage of fungal development, the shape and close association between protein and other polymers present integrity that present in the cell wall 
of the fungus is play a very important role in the dependent by giving mechanical strength, intern which performs a wide range of fundamental roles during the communication of the fungus with its environment (Gooday 1995).

We isolated different (Aspergillus niger, Aspergillus flavus, Bipolaris cyanodontis, Fusarium oxysporum, Penicillium, Trichoderma, Fusarium equiseti, Acremonium strictum, Colletotrichum gloeosporioides, and Aspergillus fumigates) fungal pathogens from food sources and subjected to DNA extraction using different protocols by comparing our fast DNA extraction method to show the efficiency and for downstream applications of DNA. Critically, the fungal wall is a multifarious organization by tranquil typically of chitin, $1,3-\beta$ - and 1,6- $\beta$-glucan, mannan, and proteins.

Primarily, monomers of $\beta$-1,4-linked N-acetylglucosamine and $\beta-1,3$-linked glucose repeats associated with formation of chitin and glucan polymers, respectively. However, considering this point of view and look up the structural association in fungal cell wall, there is abundant quantities of branched 1,3- $\beta-, 1,6-\beta$-glucan, and also evidence of Klis et al. (2002), presence of extensive crosslinking between chitin, glucan, and other wall components. Furthermore, the highly dynamic structure of cell wall involved in constant revolutionize during cell division, spore germination, branching of hyphal structures, and septum pattern in filamentous fungi. Maybe, these are activities that depend on number of hydrolytic enzymes intimately allied with the cell wall of the different fungal species. Fungal genome contains multiple glucanase/glucanosyltransferase-encoding genes. One of the possible results of gene disruption studies states that several of these enzymes have roles during development of cell-wall architecture in yeasts and filamentous fungi. Therefore, this battery of enzymes most probably helps to facilitate the complex blueprint of lysis, branching, and cross-linking that involves the glucan layers of the fungal cell wall (Adams 2004).

According to Chet and Inbar (1994), cell wall of the most of fungal species hydrolases characterized have chitinase or glucanase, and these enzymes also exhibit the transglycosylase activity. Therefore, there is possible contribution to breakage, re-forming, and re-distribution of bonds between and within polymers leading to possible remolding of the cell wall during fungal cell-wall development and morphogenesis.

Hence, the cell wall is an essential component to the cell and provides one of major defencing target to study. Currently, little is known about the cell wall of different species of filamentous fungi (Kils et al. 2002). For better understanding of the fungal cell wall and of its adaptation to various conditions, some more experimental validations are required to understand the defencing property adaptations to the external environment. The cell wall is a highly dynamic structure and able to adapt to various changes, either environmental (e.g., heat, $\mathrm{pH}$, osmolarity, and chemical compounds), developmental (e.g., mating, growth, budding, branching, and sporulation), or genetic (e.g., mutations in cell-wall-related genes) (Kollar et al. 1997; Bowman and Free 2006).

In this experimental study, S-CCI protocol is proved to be the best compared to the existing DNA extraction protocol, because, technically, S-CCI is simple, work faster, less prone to cross contamination, and inexpensive than other methods. Samples were also amenable to PCR amplification and can be used routinely to identify and screening of fungal pathogens in both clinical and laboratory settings.

Acknowledgments The authors Manukumar, H.M., and Sri Raghava greatly acknowledge the financial assistance from the Department of Biotechnology (DBT), Department of Science and Technology, Govt. of India, grant number BT/PR10338/PFN/20/922/2013, New Delhi, India, for financial assistance.

\section{Compliance with ethical standards}

Conflict of interest We declare that we have no conflict of interest in the article.

Open Access This article is distributed under the terms of the Creative Commons Attribution 4.0 International License (http:// creativecommons.org/licenses/by/4.0/), which permits unrestricted use, distribution, and reproduction in any medium, provided you give appropriate credit to the original author(s) and the source, provide a link to the Creative Commons license, and indicate if changes were made.

\section{References}

Adams DJ (2004) Fungal cell wall chitinases and glucanases. Microbiology 150(7):2029-2035

Ajay AK, Sharma K, Misra RS (2008) Rapid and efficient methods for the extraction of fungal and oomycetes genomic DNA. Gene Genome Genomic 2:57-59

Arachea BT, Sun Z, Potente N, Malik R, Isailovic D, Viola RE (2012) Detergent selection for enhanced extraction of membrane proteins. Prot Expres Purify 86(1):12-20

Bisha B, Brehm-Stecher BF (2010) Combination of adhesive-tapebased sampling and fl uorescence in situ hybridization for rapid detection of Salmonella on fresh produce. J Vis Exp 44:2308

Bolano A, Stinchi S, Preziosi R, Bistoni F (2001) Rapid methods to extract DNA and RNA from Cryptococcus neoformans. FEMS Yeast Res 1:221-224

Bollet C, Gevaudan MJ, De Lamballerie X, Zandotti C, De Micco P (1995) A simple method for the isolation of chromosomal DNA from gram positive or acid-fast bacteria. Nucleic Acids Res 19:19-25

Bowman SM, Free SJ (2006) The structure and synthesis of the fungal cell wall. BioEssays 28(8):799-808

Byrd AD, Schardl CL, Songlin PJ, Mogen KL, Siegel MR (1990) The tubulin gene of Epichloe typhina from perennial ryegrass (Lolium perenne). Curr Genet 18:347-354 
Chattopadhyay S, Kaur A, Jain S, Singh H (2013) Sensitive detection of food-borne pathogen Salmonella by modified PAN fibersimmunoassay. Bios Bioel 45:274-280

Chet I, Inbar J (1994) Biological control of fungal pathogens. Appl Biochem Biotechnol 48:37-43

Christensen MJ, Leuchtmann A, Rowan DD, Tapper BA (1993) Taxonomy of Acremonium endophytes of tall fescue (Festuca arundinacea), meadow fescue $(F$. pratensis) and perennial ryegrass (Lolium perenne). Mycolo Res 101:295-301

Desloire S, Valiente Moro C, Chauve C, Zenner L (2006) Comparison of four methods of extracting DNA from D. gallinae (Acari: Dermanyssidae). Vet Res 37:725-732

Devi SG, Fathima AA, Radha S, Arunraj R, Curtis WR, Ramya M (2015) A Rapid and Economical Method for Efficient DNA Extraction from Diverse Soils Suitable for Metagenomic Applications. PLoS One 10:7

Dieguez-Uribeondo J, Garcia MA, Cerenius L, Kozubíkova E (2009) Phylogenetic relationship among plant and animal parasites, and saprotrophs in Aphanomyces (Oomycetes). Fungal Genet Biol 46:365-376

Fredricks DN, Smith C, Meier A (2005) Comparison of six DNA extraction methods for recovery of fungal DNA as assessed by quantitative PCR. J Microbiol 43(10):5122-5128

Goltapeh EM, Aggarwal R, Pakdaman BS, Renu R (2007) Molecular characterization of Aspergillus species using amplicon length polymorphism (ALP) and universal rice primers. J Agric Technol 3:29-37

Gonzalez-Mendoza D, Moreno AQ, Zapata Perez O (2008) An improved method for the isolation of total RNA from Avicennia germinans leaves. Z Naturforsch C A J Biosci 63:124-126

Gooday GW (1995) Cell walls. In the Growing Fungus, pp. 43-62. Edited by N. A. R. Gow and G. M. Gadd. London: Chapman \& Hall

Hennequin $\mathrm{H}$ et al (1999) Identification of Fusarium species involved in human infections by $28 \mathrm{~S}$ rRNA gene sequencing. J Clin Microbiol 37(11):3586-3589

Jaykus LA (2003) Challenges to developing real-time methods to detect pathogens in foods. ASM News 69:341-347

Khan IU, Yadav JS (2004) Development of a single-tube, cell lysisbased, genus-specific PCR method for rapid identification of mycobacteria: optimization of cell lysis, PCR primers and conditions, and restriction pattern analysis. J Clin Microbiol 42:453-457

Ki JS, Chang KB, Roh HJ, Lee BY, Yoon JY, Jang GY (2007) Direct DNA isolation from solid biological sources without pretreatments with proteinase- $\mathrm{K}$ and/or homogenization through automated DNA extraction. J Biosci Bioeng 103:242-246

Kils FM, Mol P, Hellingwerf K, Brul S (2002) Dynamics of cell wall structure in Saccharomyces cerevisiae. FEMS Microbiol Rev 26:239-256

Klis FM, Mol P, Hellingwerf K, Brul S (2002) Dynamics of cell wall structure in Saccharomyces cerevisiae. FEMS Microbiol Rev 26:239-256

Kollar R, Reinhold BB, Petrakova E, Yeh HJ, Ashwell G, Drgonova J, Kapteyn JC, Kils FM, Cabib E (1997) Architecture of the yeast cell wall. Beta $(1 \rightarrow 6)$-glucan interconnects mannoprotein, beta $(1 \rightarrow)$ 3-glucan, chitin. J Biol Chem 272:17762-17775
Li XL, Yao YJ (2005) Revision of the taxonomic position of the Phoenix 9 Mushroom. Mycotaxon 91:61-73

Liu KH, Yeh YL, Shen WC (2011) Fast preparation of fungal DNA for PCR screening. J Microbiol Meth 85(2):170-172

Maaroufi Y, Ahariz N, Husson M, Crokaert F (2004) Comparison of different methods of isolation of DNA of commonly encountered Candida species and its quantitation by using a real-time PCRbased assay. J Clin Microbiol 42:3159-3163

Mathur SB, Kongsdal O (2003) Common laboratory seed health testing methods for detecting fungi. International Seed Testing Association. Mishra AK, Sharma K, Misra RS (2008) Rapid and efficient method for the extraction of fungal and oomycetes genomic DNA. Gene Genome Genomics 2(1):57-59

Moyo M, Amoo SO, Bairu MW, Finnie JF (2008) Optimizing DNA isolation for medicinal plants. South Afr. J. Bot 74:771-775

Mseddi et al (2011) A rapid and easy method for the DNA extraction from Cryptococcus neoformans. Biol Proc Online 13:5

Muller FM, Werner KE, Kasai M, Francesconi A, Chanock SJ, Walsh TJ (1998) Rapid extraction of genomic DNA from medically important yeasts and filamentous fungi by high-speed cell disruption. J Clin Microbiol 36:1625-1629

Naravaneni R, Jamil K (2005) Rapid detection of food-borne pathogens by using molecular techniques. J Med Microbiol 54:51-54

Petrisko JE, Pearl CA, Pilliod DS, Sheridan PP, Williams CF, Peterson CR, Bury RB (2008a) Saprolegniaceae identified on amphibian eggs throughout the Pacific Northwest, USA, by internal transcribed spacer sequences and phylogenetic analysis. Mycologia 100:171-180

Petrisko JE, Pearl CA, Pilliod DS, Sheridan PP, Williams CF, Peterson CR, Bury RB (2008b) Saprolegniaceae identified on amphibian eggs throughout the Pacific Northwest, USA, by internal transcribed spacer sequences and phylogenetic analysis. Mycologia 100:171-180

Prabha TR, Revathi K, Vinod MS, Shanthakumar SP, Bernard P (2012) A simple method for total genomic DNA extraction from water moulds. Curr Sci 104:345-347

Raeder U, Broda P (1985) Rapid preparation of DNA from lamentous fungi. Lett Appl Micro 1:17-20

Rogers SO, Rehner S, Bledsoe C, Mueller GJ, Ammirati JF (1989) Extraction of DNA from Basidiomycetes for ribosomal DNA hybridizations. Cana J Bot 67:1235-1243

Samuel M, Lu M, Pachuk CJ, Satshchandran C (2003) A spectrophotometric method to quantify linear DNA. Anal Biochem 313:301-306

Shin-ichi F, Takuma H (2000) DNA fingerprinting patterns of Candida species using Hinf1 endonuclease. Int J Syst Evol Microbiol 50:1381-1389

Silva ECB, Pelinca MA, Acosta AC, Silva DMF, Gomes FM, Guerra MM (2014) Comparative study of DNA extraction methodologies from goat sperm and its effects on polymerase chain reaction analysis. Gene Mole Rese GMR 13(3):6070

Wolffs P, Knutsson R, Norling B, Radstrom P (2004) Rapid quantification of Yersinia enterocolitica in pork samples by a novel sample preparation method, flotation, prior to real-time PCR. J Clin Microbiol 42:1042-1047 